\title{
A Nexus among Strategy Type, Market Orientation, Strategic Costing and Financial Sector Performance of Private Universities in Indonesia
}

\author{
Sriyono SRIYONO ${ }^{1}$
}

Received: August 01, 2020 Revised: September 06, 2020 Accepted: September 10, 2020

\begin{abstract}
This study aims to find empirical evidence of causal relationship between strategy type, market orientation, strategic management accounting (SMA) strategic costing technique, and financial sector performance of private universities in Indonesia. The research object in this study are private universities in Yogyakarta, Indonesia. Yogyakarta is chosen because universities there are one of the barometers of higher education in Indonesia, and the city has quite a number of universities. The respondents in this study are the leader (manager) of private universities in Yogyakarta, Indonesia. The data analysis is done using SEM-PLS with WarpPLS 3.0 software. The results of this study show that market orientation has significant influence on the development and implementation of SMA strategic costing technique, while strategy type does not have significant influence on the development and implementation of SMA strategic costing technique. This study also finds that the implementation of SMA strategic costing technique significantly influences the financial sector performance of private universities in Yogyakarta, Indonesia. This study provides theoretical implication regarding SMA development in universities that consider that contingency factors (market orientation) can encourage increased organizational performance. It indicates support for contingency theory that states there are no general principles that apply to all situations.
\end{abstract}

Keywords: Market Orientation, Strategy Type, Strategic Costing, Financial Sector Performance

JEL Classification Code: M41, M31, M10

\section{Introduction}

The era of globalization has triggered changes in the business environment that is increasingly dynamic with a fairly intense competition, which includes economic growth, knowledge, shorter product life-cycle, changes in organizational design of more flexible work structure, and technological developments. This condition is a challenge for managers running the organization (Baines \& LangfieldSmith, 2003; Robert H. Chenhall, 2008; Dent, 1996). To be able to thrive within a competitive environment, organizational managers must be able to understand and adapt

${ }^{1}$ First Author and Corresponding Author. Faculty of Economics and Business (FEB), Universitas Pembangunan Nasional "Veteran" Yogyakarta, Indonesia [Postal Address: JI. SWK 104, Ringroad Utara Condong Catur, Yogyakarta, 55283, Indonesia]

E-mail: sriyono@upnyk.ac.id ; sriyono.upnvyk@gmail.com

(c) Copyright: The Author(s)

This is an Open Access article distributed under the terms of the Creative Commons Attribution Non-Commercial License (https://creativecommons.org/licenses/by-nc/4.0/) which permits unrestricted non-commercial use, distribution, and reproduction in any medium, provided the original work is properly cited. to existing environmental conditions (Dixon \& Smith, 1993). Therefore, the implementation of strategic management in the organization is very necessary. Strategic management is related to environmental observation, strategy formulation, strategy implementation, evaluation, and control (Wheelen \& Hunger, 1996, 2012). The results of environmental observations are used as a reference in developing strategic plan of the organization that includes the vision, mission, goals, and objectives of the organization within a certain period of time. To achieve these, organizational structures and design are required, as well as the implementation of management functions such as organizing, implementing, budgeting, control and evaluation, and feedback (Wheelen \& Hunger, 2012). The implementation of management functions is a part of management accounting practices. This shows the greater role of management accountants in providing information to management, which is used as a basis for management decision-making. Thus, the development and implementation of management accounting practices must be aligned with the organization's strategic plan.

Decision makes use accounting systems and information to achieve organizational goals by aligning five key 
organizational factors, namely, mission statement, goals, objectives, operational strategies, and organizational performance measurement (Smith, 2005). One of the developments of management accounting is strategic management accounting (SMA), which is an integral part of a system to support and produce information as a basis for decision making (Smith, 2005). The development of SMA is a major step toward changes in costing and management accounting systems to generate and provide relevant information for the organization in order to achieve sustainable competitive advantage (Spicer, 1990). According to Simmonds (1981), SMA is an accounting approach that provides and analyzes management accounting data related to business and its competitors to be used in developing and monitoring business strategy (Roslender \& Hart, 2003). SMA is seen as a form of management accounting development oriented towards strategic management (formulation, implementation, and control of strategy) and marketing management, as well as other managerial functions (Bromwich, 1990; Roslender \& Hart, 2002, 2003, 2006). SMA is more externally oriented, focused on customers, competitors, and the market, and is oriented towards the future that provides a strategic orientation. Other researchers, such as Tayles et al. (2002); Tayles et al. (2007); Nixon and Burns, (2012) view SMA to be more oriented to internal resources and organizational capability that are used to support competitive ability. According to Furrer et al. (2008); Cummings and Daellenbach (2009); and Nixon and Burns (2012), this orientation is important considering that these resources are the focus of strategic management.

Research on the implementation of SMA is mostly carried out in profit-oriented organizations, while research on SMA in non-profit-oriented organizations (public-sector organizations) is still relatively limited. Profit-oriented organizations (private organizations) and public-sector organizations have different nature and characteristics. These differences can be seen from the objectives of the organization, sources of financing, accountability patterns, organizational structure, budget characteristics, affected stakeholders, and the accounting system used (Mardiasmo, 2002). University is a form of public-sector organization. In changing environmental conditions and increasingly high levels of competitions, the development and formulation of strategy by universities is needed. The study conducted by Yani (2014) showed that private universities have implemented alternative strategies to survive in a changing environment. Buckland (2009) found that the development of structure and strategic management technique in universities in UK has considered various factors that influence academic life. SMA development of public sector organization can be done by adopting SMA of business organization (Hutaibat, 2011).
The use of SMA information can assist managers in adopting and implementing organizational plans in responding to environmental changes, and it can help managers to make decision and establishing strategies in achieving organizational goals (Mia \& Clarke, 1999). The development of system and organizational structure must be able to adapt to both external and internal (contingency factor) environmental changes of the organization, thus achieving predetermined organizational performance (Chenhall, 2003). The effectiveness of the design of an organizational structure and systems depends on its ability to adapt to changes in both the external and internal environment. Haldma and Lääts (2002) found changes in cost accounting practices and management accounting regarding business and accounting environmental changes (external contingency factor), as well as technological aspect (internal contingency factor).

The study from Sriyono and Rahmawati (2014) showed that the majority of private universities in Yogyakarta have implemented SMA techniques. Zenita et al. (2015) conducted research on the implementation of SMA in banking institutions in Pekanbaru, and found that the use of SMA information has an influence on managerial performance, which is strengthened by the manager's confidence in achieving goals, utilizing, managing, and implementing actions (self-efficacy). Research on the application of SMA in public-sector organizations in Indonesia is still relatively limited compared to private organizations. There are differences in the nature and characteristics between private and public sector organizations, which makes this study interesting, especially in public-sector organizations. This study examines a nexus between strategy type, market orientation, SMA strategic costing technique, and financial sector performance in private universities in Indonesia.

\section{Literature Review}

The relationship between the variables of strategy type, market orientation, SMA strategic costing technique, and organizational performance is based on contingency theory. Contingency theory is an approach to organizational behavior that explains how contingency factors affect the organization's functions and designs. Contingency theory claims that there is no best way to manage, lead, or make decision in an organization.

According to Galbraith (1973), there are two basic assumptions in contingency theory: (1) there is no best way to regulate the organization, and (2) there is no effective way of organizing, so it depends on various things, including environment and technology. Contingency theory is based on the idea that organizational management can run well and smoothly if organizational leaders are able to pay attention to and solve certain situations at hand, and that each situation must be analyzed independently (Wursanto, 2003). The 
essence of contingency theory is "there is no one best way that can be used in all environmental conditions (situation)" (Gudono, 2014). There are no general principles that apply to all situations, so it is necessary to conduct a separate analysis of each situation faced by the organization. Contingency theory hypothesizes that organizational structure is a function of relationships that are simultaneously determined by the external and internal environmental factors of the organization, characteristics of the organization, and other organizational factors (Anderson \& Lanen, 1999). The results also found that organizational characteristics are directly related to the effectiveness of management information systems (Le et al., 2020). Therefore, the development of systems and structures of the organization including SMA must consider organizational characteristics, because the effectiveness of the systems and structures of the organization depend on the fit between organization and its environment.

Otley (1980) stated that the basic concept of contingency approach is that there is no concept or design of organization that can be implemented effectively. SMA, as a general approach to accounting in organizational strategic positions, is an attempt to integrate insights from management accounting and marketing management within a strategic management framework (Roslender \& Hart, 2003). The development of SMA for higher education is believed to be a system adopted from a strategic framework (Hutaibat et al., 2011). According to Hutaibat (2011), SMA development in business organization can be adopted for public sector organization, including university.

Organizational management is highly dependent on various situations, such as environmental uncertainty (Kreitner \& Kinicki, 2001). Contingency theory states that in practice, everything depends on the contingency situation. There are no general principles that apply to all situations, so it is necessary to conduct a separate analysis of each situation faced by the organization. Therefore, the development of SMA needs to consider various contextual factors, including contingency factors.

\subsection{The Influence of Strategy Type toward SMA Strategic Costing Technique}

SMA is known as a set of strategically-oriented accounting techniques, and the involvement of accountants in the strategic decision-making process of the organization (Simon \& Guilding, 2008b). The practices of SMA strategic costing is related to determination, analysis, and management of costs that is oriented to organizational strategy. The practices of SMA Strategic Costing consist of five steps, namely, attribute costing, target costing, value-chain costing, life-cycle costing, and quality costing (Cravens \& Guilding, 2001; Guilding et al., 2000; Guilding \& McManus, 2002).
To achieve the vision, mission, goals, and objectives of the organization, management accounting practices are needed. Management accounting practices that can support the achievement of an organization's vision, mission, goals, and objectives are management accounting practices that are appropriate and in line with the organization's strategy. Therefore, the development and application of management accounting practices must consider the choice of organizational strategy. Thus, organizational strategy is one of the contingency factors in the development of SMA (Hoque, 2004; Langfield-Smith, 1997).

Strategy is the main method and tactic designed systematically (strategic planning) in carrying out management functions, directed at the goals of the organization's strategy (Nawawi, 2005). Strategy of universities is formulated in order to achieve the vision, mission, goals, and objectives of the university. To implement organizational strategy, organizational structures and designs are needed, as well as the implementation of management functions. According to Terry (1958) and Mainduh (1997), the basic functions of management include: planning, organizing, actuating, and controlling (Torang, 2013). Thus, the development and implementation of management accounting practices is also included in the implementation of management function. Cost leadership strategy becomes one of the alternatives of strategic choices that can be implemented in private universities (Yani, 2014). Universities that apply cost leadership strategy tend to direct their work program preparation at efforts to meet the required quality standards by keeping the cost of education relatively low. The implementation of strategic costing that is also a part of SMA practices implementation in universities needs to consider these conditions. Therefore, the choice of strategy is one of the factors that need to be considered in the development and implementation of SMA strategic costing practices in universities.

Several research results indicate that SMA development is influenced by the choice of organizational strategy. Simons (1987) found that companies that implement a differentiation strategy emphasize the use of strict budgets, formal output monitoring, and forecast data rather than formal cost control. The sophistication of an SMA system does not automatically correlate with superior performance, but the fit between the identification of contingency factors and the management accounting system does (Simons, 1987). Chenhall (2003) found that conservative strategies are correlated with management control system design. Roslender and Hart (2003) found that the practice of management accounting and marketing management has an impact on SMA practices in UK. The contingency factors of strategic positioning and strategic mission have correlation in the use of SMA technique in large manufacturing companies in Italy (Cinquini \& Tenucci, 2007). 
Strategic position plays a contingency role in the use of SMA technique (Cinquini \& Tenucci, 2007). Simon and Guilding (2008a) found that prospector strategy type positively influences the successful implementation of SMA in large companies in Slovenia. Fowzia (2011) stated that corporate strategy (strategic pattern, strategic mission, and strategic positioning) influences SMA implementation in manufacturing companies in Bangladesh. The research results from Chenhall et al. (2011) showed that strategy affects adoption and design of management control system. Mohamed and Jamil (2013) found the relationship between business strategy and the design of the performance measurement system for small and medium hotels in Malaysia. There is a relationship between product differentiation strategies, innovation, and MCS design (Beuren \& Oro, 2014). Chong and Chong (1997) stated that strategic business unit and environmental uncertainty influences MCS design in manufacturing companies in Australia. The prospector strategy type is related to information system (SMA) (Abernethy \& Guthrie, 1994). Maassen and Potmaw (1990) found that in universities, the best strategic decisionmaking model is the interpretive model. SMA development for universities is believed to be a system adopted from strategic framework (Hutaibat et al., 2011). From the results of previous studies, it can be concluded that the type of strategy influences the development of design and structure in organizations, including SMA development. Universities that implement cost leadership strategy tend to have higher intensity of SMA implementation.

\subsection{The Influence of Market Orientation toward SMA Strategic Costing Technique}

Market orientation is a set of concrete actions that allow companies to maintain variations in market demand and supply, and provide appropriate responses to various changes (Varadarajan \& Jayachandran, 1999). Organizations that make market orientation as organizational culture will focus on external market needs; and market demands will become the basis for strategic formulation of business units in the organization (Slater \& Narver, 1995). To maintain the existence of the organization, understanding and creating value for customers is very important. Customer value relates to the attributes of the product/service such as characteristics, features, and benefits of the product/service required by customers to meet their needs. In the context of market orientation, understanding and creating value for customers requires the coordination of all functional areas and activities in the organization, including marketing and accounting. Understanding of customers requires the acquisition and dissemination of information about customer needs (Kohli \& Jaworski, 1990). Therefore, understanding of product/ service attributes needed by customers will determine the organizational strategy. Management accounting practice is required in implementing organizational strategy. Management accountants contribute to the creation of value for customers by providing product/service attributes (features, functions, and benefits) according to customer needs.

Market-oriented universities are indicated by the provision and adjustment of the attributes of educational product/service such as characteristics, features, and benefits of educational products/services aimed at meeting the needs of university stakeholders, including prospective students, industry, and business. Prospective students are public targets in an effort to meet the needs of the number of students as well as the financial needs of a university. Industry and business become financial support partners, student practices, or users. Determining the target market (prospective students) is one of the forms of university strategy in getting students. SMA development for universities is believed to be a system adopted from a strategic framework (Hutaibat et al., 2011). Therefore, the organization's market orientation becomes one of the factors that need to be considered in the development and implementation of management accounting practices (SMA) in universities (Daft, 2013; Haldma \& Lääts, 2002). Several research results (Cinquini \& Tenucci, 2007; Guilding \& McManus, 2002; Haldma \& Lääts, 2002; Hyvönen, 2008; Mia \& Clarke, 1999; Noordin et al., 2009; Roslender \& Hart, 2003; Simon, 2007) supported market orientation to be one of the factors that needs to be considered in the development and implementation of management accounting practices (SMA). Previous studies showed that market orientation influences system design and organizational structure.

\subsection{The Influence of SMA Strategic Costing Technique toward Organizational Performance}

Performance is a measure of the results of work performed using mutually agreed criteria (Robbins, 1994). Performance shows the results obtained by an organization, both profit-oriented and non-profit-oriented organizations for a certain period of time (Fahmi, 2014). Bastian (2001) defined performance as the level of achievement of an implementation of an activity, program, or policy in realizing the goals, objectives, mission, and vision contained in the organization's strategic formulation. Uha (2013) distinguishes performance into two: (1) individual performance, which is the work of employees both in terms of quality and quantity based on predetermined work standards, and (2) organizational performance, which is a function of the results of work/activities in the organization affected by internal and external factors of the organization to achieve the goals set over a certain period of time. Ruekert et al. (1985) defined organizational performance 
as the effectiveness of achieving organizational goals, the efficient use of input to produce certain outputs, and the organization's ability to adapt to environmental changes (Homburg et al., 1999). Performance is a description of the level of achievement of the implementation of an activity/ program/policy in achieving vision, mission, goals, and objectives of the organization, which are contained in the strategic formulation of the organization (Bastian, 2001).

In universities, the goals and objectives stated in the organizational strategic plan are the performance targets that will be achieved within a certain period of time. The strategic plan contains the vision, mission, objective strategy, and main strategy of the organization. One of the indicators of universities performance is the quality of education services. Accreditation is a form of assessment (evaluation) of the quality and feasibility of university or study program (BAN-PT, 2016). Therefore, the improvement of the quality of education services needs to be carried out in sustainable manner. Several factors that support the improvement of sustainable educational service quality and the achievement of institutional accreditation, among which are financing, facilities and infrastructure, and information system. A good financing sector will be able to support the implementation of quality academic programs in higher education. Management of universities facilities and infrastructure is good if the planning, procurement, use, maintenance, upgrades, inventory, and write-off processes of assets are carried out properly, so that it will be effective in supporting academic activities. A good information system exists when the input, process, and output of the information is supported by sufficient information technology to support the quality assurance of university administration.

In the condition of increasingly high levels of competition, universities are required to not only meet the quality standards required by the government, but also to have better quality than other universities. Therefore, managers of university are required to be more precise and accurate in making decisions. They are not only need historical internal financial information, but also other relevant information (non-financial, external, and prospective) relating to customers and competitors (Baines \& Langfield-Smith, 2003; McManus, 2013). This information is needed so that decision making, planning, and controlling can be carried out appropriately, thus universities can achieve competitive advantage and improve organizational performance.

Conventional management accounting practices can only provide financial, internal, and historical information system, while non-financial, external, and prospective information system can be provided by SMA. The use of SMA information can assist managers in adopting and implementing organizational plans in response to environmental changes as well as in making decisions and establishing strategies in achieving organizational goals
(Mia \& Clarke, 1999). There are four factors that affect the intention to apply management accounting to companies in Vietnam: (1) performance expectancy; (2) effort expectancy; (3) perceived trust; and (4) subjective norms (Nguyen \& Le, 2020).

Several studies indicate that SMA implementation can encourage an increase in organizational performance. Marin (2012) found that the use of strategic management system positively influences performance. The study from Aksoylu and Aykan (2013) showed that SMA technique positively influences manufacturing companies performance in Kayseri, Turkey. Zenita et al. (2015) examined SMA implementation in banking institutions in Pekanbaru, and found that the use of SMA information affects managerial performance. Alsoboa et al. (2015) stated that SMA strategic costing technique consisted of costing ( $\mathrm{ABC}$ ), target costing, and cost of quality positively influences performance in Jordanian Listed Manufacturing Companies, both financial and market performance. S. Alsoboa et al. (2015) also found that all SMA strategic costing technique, except attribute costing, positively influence JLMC production performance. The study from Alsoboa and Alalaya (2015) indicated that the implementation of SMA competitor accounting technique provides significant contribution in encouraging competitive advantage achievement in manufacturing companies in Jordan. Zenita et al. (2015) added that the use of SMA information in banking institution in Pekanbaru influences managerial performance, strengthened by managers' selfconfidence. Phornlaphatrachakorn and Peemanee (2020) found that integrated performance measurement as an SMA approach positively influences organizational commitment, organizational citizenship behavior (OCB), and company success. Organizational commitment positively influences OCB and company success, while OCB positively influences company success. The implementation of strategy that is integrated and aligned with performance indicators as an effort to achieve university quality has a central role in the competitive strategy of universities in Romania (Moldovan, 2012). The research result from Hutaibat (2011) indicated that value chain analysis is one of the SMA practices that is useful to identify critical success factors and for developing competitive advantage in UK universities. From the results of the study, it can be concluded that SMA implementation influences organizational performance. This is in line with SMA approach that is normatively mentioned that management accounting practices aligned with organizational strategy can improve better performance.

\subsection{Hypotheses}

$\boldsymbol{H}_{I}:$ Strategy Type positively influences the implementation of SMA Strategic Costing Technique practice in private universities in Indonesia 
$\boldsymbol{H}_{2}:$ Market Orientation positively influences the implementation of SMA Strategic Costing Technique in private universities in Indonesia

$\boldsymbol{H}_{3}:$ SMA Strategic Costing Technique positively influence the performance of financial sector of private universities in Indonesia

\section{Research Method}

The research object in this study are private universities in Yogyakarta, Indonesia. Yogyakarta is chosen because universities in Yogyakarta are one of the barometers of higher education in Indonesia, and as a city of students, Yogyakarta has quite a number of universities.

The sampling technique in this study is using census sampling method, conducted by taking all members of the population as a sample (Sugiyono, 2010). The respondents in this study are leaders (managers) of private universities in Yogyakarta, Indonesia. This selection is made considering that they sufficiently understood the strategy chosen and applied by the universities, as well as understood the management both from financial and non-financial aspects, which are related to the preparation and implementation of work program and budgets of the universities.

\subsection{Operational Definition and Variable Measurement}

Performance is the level of achievement of the implementation of an activity/program/policy in realizing the goals, objectives, mission, and vision of the organization, which are contained in the strategic formulation of the organization (Bastian, 2001). Organizational performance (university) is measured using the standard accreditation forms for higher education institutions, which consists of five indicators: (1) ownership of fund management; (2) mechanism for determining cost of education; (3) financing policy for students who have academic potential, but are economically disadvantaged; (4) monitoring and evaluation of funding and performance; and (5) financial report auditing by external auditors (BAN-PT, 2016). The performance of financial sector of university is measured with ordinal scale using 5-point Likert scale, namely: (1) "Very Poor", (2) "Poor", (3) "Moderate", (4) "Good", and (5) "Very Good".

SMA is a set of strategic oriented accounting techniques and the involvement of accountants in the organization's strategic decision-making process (Simon \& Guilding, 2008a). SMA Strategic Costing technique is measured by developing SMA instruments from Simon and Guilding (2008a), which consists of five indicators: (1) the education costing system can provide an overview of the characteristics of lucrative educational products/services; (2) determination of the educational products/services cost has considered all cost components; (3) cost identification and control; (4) determination of education rates; and (5) cost of educational products/services is based on educational service activities. SMA strategic costing technique is measured using 5-point Likert scale, namely: (1) "Never", (2) "Rarely", (3) "Sometimes", (4) "Ever", and (5) "Always" (Simon \& Guilding, 2008a).

Strategy type in this study is measured using Porter's type of strategy (David, 2011), which is cost leadership strategies that emphasize producing standardized products/services at relatively low costs for price/rates sensitive consumers. Type of strategy instrument is measured by developing the cost leadership strategy instruments from Nimtrakoon (2009), and using ordinal scale with 5-point Likert scale, namely: (1) "Strongly Disagree", (2) "Disagree", (3) "Neutral", (4) "Agree", and (5) "Strongly Agree".

Market orientation is defined as the most effective and efficient organizational culture to create behaviors that can produce the best for customers and produce superior performance for the organization (Narver \& Slater, 1990). The instrument used to measure market orientation in this research is developed from Narver and Slater (1990), which consists of three dimensions: (1) customer orientation, which is an understanding of customers to create superior value in a sustainable manner; (2) competitor orientation, which is organizational understanding of the strengths, weaknesses, capabilities, and strategies of competitors, both current and potential competitors in the short and long term; and (3) inter-functional coordination, which is coordination related to the use of organizational resources in creating superior value for target customers. To achieve competitive advantage and organizational goals, organization needs to determine the needs and wants of the target market and providing satisfaction that is more efficient and effective than the competition (Kotler, 2000). Market Orientation is measured using ordinal scale with 5-point Likert scale, namely: (1) "Strongly Disagree", (2) "Disagree", (3) "Neutral", (4) "Agree", and (5) "Strongly Agree".

\subsection{Data Analysis Technique}

The data analysis technique used to test the strategy type, market orientation, SMA strategic costing technique, and performance of financial sector in private universities in Indonesia is Warp Partial Least Square - Structural Equation Modeling (WarpPLS - SEM), which is a powerful soft-modeling analysis method (Hair et al., 2014; Latan \& Ghozali, 2012; Sholihin \& Ratmono, 2013). 
Table 1: Variable Measurement

\begin{tabular}{|l|c|l|}
\hline Variable/Dimension & Indicator & \multicolumn{1}{|c|}{ References } \\
\hline 1. Performance of Financial Sector of University & $\begin{array}{c}5 \text { indicators } \\
\text { (BAN PT) }\end{array}$ & - BAN PT (2008, 2011, 2016) \\
\hline $\begin{array}{l}\text { 2. SMA Strategic Costing Practices } \\
\text { 3indicators }\end{array}$ & $\begin{array}{l}- \text { Simon and Guilding (2008) } \\
\text { Guilding et al. (2000). }\end{array}$ \\
\hline $\begin{array}{l}\text { Strategies) } \\
\text { 4. Market Orientation } \\
\text { 1. Customer Orientation } \\
\text { 2. Competitor Orientation } \\
\text { 3. Inter-functional Coordination }\end{array}$ & 8 indicators & - David (2011) \\
\hline
\end{tabular}

Table 2: Respondents' Description

\begin{tabular}{|c|c|c|c|c|}
\hline \multirow{2}{*}{ No. } & \multirow{2}{*}{ Position } & \multicolumn{2}{|c|}{ Respondents } & \multirow{2}{*}{$\begin{array}{l}\text { Average length of } \\
\text { service (Years) }\end{array}$} \\
\hline & & Number & $\%$ & \\
\hline 1 & Rector (Chairman) of University & 26 & $15 \%$ & 1.58 \\
\hline 2 & Vice Rector II (General Administration and Finance) & 8 & $4 \%$ & 6.00 \\
\hline 3 & Head of Bureau for General Administration and Finance & 8 & $4 \%$ & 10.50 \\
\hline 4 & Assistant of Vice Rector II (Finance and General Administration) & 16 & $9 \%$ & 9.75 \\
\hline 5 & Dean & 35 & $20 \%$ & 1.29 \\
\hline 6 & Deputy Dean (Finance and General Administration) & 28 & $16 \%$ & 1.93 \\
\hline \multirow[t]{2}{*}{7} & Director, Vice Director, Head of Institution, and others & 58 & $32 \%$ & 1.33 \\
\hline & Number & 179 & $100 \%$ & \\
\hline
\end{tabular}

\section{Results and Discussion}

\subsection{Respondents' Description}

The number of questionnaires that is processed is 179 questionnaires from private universities in Yogyakarta, Indonesia. All respondents in the study held positions at universities with an average of more than 1 years of service (Table 2). This condition assures that the data submitted is good enough and can be justified.

\subsection{Model Measurement Analysis (Measurement Model or Outer Model)}

The results of measurement model analysis shows that the construct indicators used in this study (strategy type, market orientation, SMA strategic costing technique, and performance of financial sector of university) has a loading factor value above 0,5 and the significance level of $\mathrm{p}$-value $<$ 0,05 . It can be concluded that all construct indicators in this study are valid, which means that it has the ability to explain the construct. The discriminant validity analysis results also show that the magnitude of the correlation of the same construct (the root value of average variances extracted) is higher than the correlation with different constructs, so it can be concluded that the instruments in this study have a good level of discriminant validity.

The test results of construct reliability of strategy type, market orientation, SMA strategic costing technique, and performance of financial sector of private universities in Indonesia show that the composite reliability coefficients and Cronbach's Alpha value above 0,7 . Thus, it can be concluded that the instruments used to measure the constructs has the level of accuracy and consistency that is quite good (reliable).

\subsection{Evaluation Criteria of Model Fit Indices of Structural Model}

The results of the fit indices test (model fit indices) of the structural model (inner model) of the causal relationships 
of the constructs of strategy type, market orientation, SMA strategic costing technique, and performance of financial sector of private universities in Indonesia shows the value of average path coefficient (APC) of 0,400 with the significance level shown by $\mathrm{p}$-value that is smaller than 0,001 and the value of average R-squared (ARS) of 0,313 with the significance level shown by p-value that is smaller than 0.001 , and the average variance inflation factor (AVIF) value of 1,039 , which is smaller than 5 (Table 3). From these results, it can be concluded that the structural model of the relationship between strategy type, market orientation, SMA strategic costing technique, and performance of financial sector of private universities is fit, thus it can be used for the analysis of relationship between constructs and hypothesis test.

\subsection{Structural Model Analysis}

The results of structural model evaluation can be seen in Table 4. The coefficient of determination (R-squared) of the structural model of SMA strategic costing technique construct is 0,404 . Thus, it can be concluded that the influence of strategy type and market orientation toward SMA strategic costing technique is $40,4 \%$, while the $59,6 \%$ is influenced by other variables outside this research model. Besides, the influence of SMA strategic costing technique towards the performance of financial sector of private universities is $22,1 \%$ while the $77,9 \%$ is influenced by other variables outside the research model. The Q-squared coefficient of all endogenous constructs is above 0,2 (moderate structural model). From this result, it can be concluded that the predictor latent variable (exogenous) has the predictive relevance of endogenous variable in the structural model.

\subsection{Hypothesis Test Results of the Influence of Strategy Type and Market Orientation toward SMA Strategic Costing Technique in Private Universities in Indonesia}

The test results of hypothesis 1 (H1) of the influence of strategy type on the implementation of SMA strategic costing technique in private universities in Yogyakarta, Indonesia, shows the p-value of 0,060 (greater than 0,05) and negative path coefficients of 0,134 (Table 5). This shows that statistically, strategy type does not significantly influence SMA strategic costing technique in private universities in Yogyakarta. The direction of the negative coefficient indicates that universities that tend to implement cost leadership strategy have lower intensity of implementing SMA strategic costing technique. This condition is supported by the perception of 179 respondents that only $36 \%$ private universities implemented cost leadership strategy, as $26 \%$ applied a differentiation strategy, and $38 \%$ of respondents stated that universities in determining the choice of strategy types are still not yet focused (doubtful) between the choice of cost leadership strategy and differentiation strategy. This doubt or hesitation in determining the strategy types indicates that there is a lack of clarity about the strategy applied to university. The results of this study does not support the previous studies conducted by Chong and Chong (1997), Abernethy and Guthrie (1994), Cinquini and Tenucci (2007), Simon and Guilding (2008a), Chenhall et al. (2011), Fowzia (2011), Mohamed and Jamil (2013), and Beuren and Oro (2014) who found that there is an influence of the choice of strategy types on the development of organizational structures and systems, including SMA in companies.

Table 3: Evaluation of Model Fit Indices of Causal Relationship Model between Construct

\begin{tabular}{|c|c|c|c|c|c|}
\hline \multirow{2}{*}{ Number } & \multirow{2}{*}{ Indicator } & \multicolumn{2}{|c|}{ Output } & \multirow{2}{*}{ Criteria } & \multirow{2}{*}{$\begin{array}{c}\text { Model } \\
\text { Evaluation }\end{array}$} \\
\hline & & Result & P Value & & \\
\hline 1 & Average path coefficient (APC) & 0.400 & $P<0.001$ & $p$ value $<0,05$ & Good \\
\hline 2 & Average R-squared (ARS) & 0.313 & $P<0.001$ & $\mathrm{p}$ value $<0,05$ & Good \\
\hline 3 & Average variance inflation factor (AVIF) & 1.039 & & $<5,00$ & Good \\
\hline
\end{tabular}

Table 4: R-squared and Q-squared Results of Structural Model Construct

\begin{tabular}{|c|l|c|c|}
\hline Number & \multicolumn{1}{|c|}{ Construct } & R-squared Coefficients & Q-squared Coefficients** $^{*}$ \\
\hline 1 & SMA Strategic Costing & 0.404 & 0.418 \\
\hline 2 & Performance of Financing & 0.221 & 0.221 \\
\hline
\end{tabular}

Note: * The higher the R-squared value, the better the model; ${ }^{* *} \mathrm{Q}$-squared value must be greater than zero 
Table 5: Analysis Results of Structural Model of Strategy Types, Market Orientation, SMA Strategic Costing Technique, and Performance of Financial Sector of Private Universities in Indonesia

\begin{tabular}{|l|c|c|c|}
\hline Hypothesis & Path Coefficients & P Values & Finding \\
\hline Strategy Type à Technique SMA - Strategic Costing & -0.134 & 0.060 & Not significant \\
\hline Market Orientation à Technique SMA - Strategic Costing & 0.596 & $<0.001$ & *Significant \\
\hline Technique SMA - Strategic Costing à Performance in the financing sector & 0.471 & $<0.001$ & *significant \\
\hline
\end{tabular}

Note: * indicates significant at $5 \%$ level of significance based on t-statistics

The test results of hypothesis $2(\mathrm{H} 2)$ of the influence of market orientation on the implementation of SMA strategic costing technique in private universities in Yogyakarta, shows the $\mathrm{p}$-value smaller than 0,001 and the positive value of path coefficient of 0,596 (Table 5). The p-value that is smaller than 0,05 shows that statistically, market orientation significantly influences the intensity of SMA strategic costing technique implementation in private universities in Yogyakarta. It can be concluded that market orientation positively influences SMA strategic costing technique implementation in private universities in Yogyakarta, thus, $\mathrm{H} 2$ is supported. It is supported by the perception from 179 respondents, as $88 \%$ universities are market-oriented. It shows that marketoriented universities will tend to implement SMA strategic costing technique. The higher the attention of higher education managers to customers, competitors, and inter-functional coordination, the higher the SMA strategic costing technique implementation would be. Universities commitment to service and complaints from customers and their fast response to consumer need will increase the implementation level of SMA strategic costing technique.

In addition, greater universities managers' anticipation of the actions and strategies of competitors, supported by the implementation of functions in an integrated organization, will encourage and motivate all employees to contribute in creating higher values to customers along with higher intensity of SMA implementation. Good understanding of customers to create sustainable superior value will guarantee organizational existence. The results of this study support several previous studies (Cinquini \& Tenucci, 2007; Guilding \& McManus, 2002; Haldma \& Lääts, 2002; Hyvönen, 2008; Mia \& Clarke, 1999; Noordin et al., 2009; Phornlaphatrachakorn \& Na-Kalasindhu, 2020; Roslender \& Hart, 2003; Simon, 2007) that market orientation of organization becomes one of the factors that need to be considered in SMA development and implementation.

\subsection{Hypothesis Test Results of the Influence SMA Implementation toward Performance of Financial Sector of Private Universities in Indonesia}

The test results of hypothesis $3(\mathrm{H} 3)$ of the influence of SMA strategic costing implementation on the performance of financial sector of private universities in Yogyakarta, shows the significance level ( $p$ value) of $<0,001$ (smaller than 0,05 ) and the path coefficient value of 0,471 (Table 5). Smaller p-value of 0,05 shows that statistically, the implementation of SMA strategic costing technique implementation significantly influences the performance of financial sector of private universities in Yogyakarta. It can be concluded that hypothesis 3 (H3), which stated that SMA strategic costing implementation positively influences the performance of financial sector of private universities in Yogyakarta, is supported. Positive path coefficient means that universities, which tend to implement SMA strategic costing technique have better performance in financial sector. It is supported by the perception from respondents, that $80,78 \%$ universities has high intensity of SMA strategic costing implementation, and $60 \%$ respondents stated that the performance of financial sector of private universities is good and very good. SMA strategic costing technique implementation will encourage the improvement of performance in financial sector in universities. This results support the previous studies, which stated that companies that implement SMA can encourage better performance achievement (Aksoylu \& Aykan, 2013; Banker et al., 2011; Cadez \& Guilding, 2012; Hassan et al., 2011; Marin, 2012; Phornlaphatrachakorn \& Peemanee, 2020; Said et al., 2010; Simon, 2007; Zenita et al., 2015).

\section{Implication}

This study provides theoretical implication in the form of empirical evidence that SMA strategic costing technique has been developed and implemented in private universities in Yogyakarta, Indonesia. SMA development in universities is carried out by adopting and developing private sector SMA, which is then adjusted to the nature, characteristics, and environment of the universities. SMA development in universities that consider contingency factors (market orientation) can encourage increased organizational performance. Therefore, these results indicate support for contingency theory that there are no general principles that apply to all situations, so it is necessary to carry out a separate analysis in every situation faced by the organization.

The practical implication in this study is that Yogyakarta, as a city of education and a barometer of higher education in Indonesia, has a wide variety of universities, thus the trend 
that occurs in those universities has the potential to occur in other universities in Indonesia. Therefore, the results of this study can be used as a reference for the management of university in Indonesia in preparing and developing SMA practices, thus, it can encourage the achievement of organizational goals and objectives.

\section{References}

Abernethy, M. A., \& Guthrie, C. H. (1994). An empirical assessment of the fit between strategy and management information system design. Accounting and Finance, 34(2), 49-66.

Aksoylu, S., \& Aykan, E. (2013). Effects of Strategic Management Accounting Techniques on Perceived Performance of Businesses. Journal of US-China Public Administration, 10(10), 1004-1017.

Alsoboa, S., Al-Ghazzawi, A., \& Joudeh, A. (2015). The Impact of Strategic Costing Techniques on the Performance of Jordanian Listed Manufacturing Companies. Research Journal of Finance and Accounting, 6(10), 116-128.

Alsoboa, S. S., \& Alalaya, M. M. (2015). Practices of Competitor Accounting and its Influence on the Competitive Advantages: An Empirical Study in Jordanian Manufacturing Companies. Global Journal of Management and Business Research: Accounting and Auditing, 15(3), 12-23.

Anderson, S. W., \& Lanen, W. N. (1999). Economic transition, strategy and the evolution of management accounting practices: the case of India. Accounting, Organizations and Society, 24(56), 379-412.

Baines, A., \& Langfield-Smith, K. (2003). Antecedents to management accounting change: A structural equation approach. Accounting, Organizations and Society, 28(6-7), 675-698.

BAN-PT. (2016). Accreditation of Higher Education Institutions. Jakarta, Indonesia: BAN PT.

Banker, R. D., Hu, N., Pavlou, P. A., \& Luftman, J. (2011). CIO Reporting Structure, Strategic Positioning and Firm Performance. MIS Quarterly, 35(2), 487-504.

Bastian, I. (2001). Public Sector Accounting (1 ${ }^{\text {st }}$ ed.). Yogyakarta, Indonesia: Badan Penerbit Fakultas Ekonomi UGM.

Beuren, I. M., \& Oro, I. M. (2014). Relationships between Differentiation Strategies, Innovation and Management Control Systems. RAC - Revista de Administracao Contemporanea, 18, 285-310.

Bromwich, M. (1990). The Case For Strategic Management Accounting: The Role Of Accounting Information For Strategy In Competitive Markets. Accounting, Organizations and Society, 12(1/2), 27-46.

Buckland, R. (2009). Private and Public Sector Models for Strategies in Universities. British Journal of Management, 20(4), 524-536.
Cadez, S., \& Guilding, C. (2012). Strategy, strategic management accounting and performance: a configurational analysis. Industrial Management \& Data Systems, 112(3), 484-501.

Chenhall, R. H. (2003). Management control system design within its organizational context: Findings from contingencybased research and directions for the future. Accounting, Organizations and Society, 28(2-3), 127-168.

Chenhall, R. H. (2008). Accounting for the horizontal organization: A review essay. Accounting, Organizations and Society, 33(45), 517-550.

Chenhall, R. H., Kallunki, J. P., \& Silvola, H. (2011). Exploring the Relationships between Strategy, Innovation, and Management Control Systems: The Roles of Social Networking, Organic Innovative Culture, and Formal Controls. Journal of Management Accounting Research, 23(1), 99-128.

Chong, V. K., \& Chong, K. M. (1997). Strategic choices, environmental uncertainty and SBU performance: A note on the intervening role of management accounting systems. Accounting and Business Research, 27(4), 268-276.

Cinquini, L., \& Tenucci, A. (2007). Is The Adoption Of Strategic Management Accounting Techniques Really "StrategyDriven"? Evidence From A Survey. Cost and performance in services and operations Trento (Italy), 8-20. MPRA (Munich Personal RePEc Archive).

Cravens, K. S., \& Guilding, C. (2001). An empirical study of the application of strategic management accounting techniques. Advances in Management Accounting, 10, 95-124.

Cummings, S., \& Daellenbach, U. (2009). A guide to the future of strategy? The history of Long Range Planning. Long Range Planning, 42(2), 234-263.

Daft, R. L. (2013). Organization Theory and Design (1 $11^{\text {th }}$ ed.). Boston, MA: Cengage Learning.

David, F. R. (2011). Strategic Management: Concepts and Cases (13th ed.). Upper Saddle River, NJ: Prentice Hall.

Dent, J. F. (1996). Global competition: Challenges for management accounting and control. Management Accounting Research, 7(2), 247-269.

Dixon, R., \& Smith, D. (1993). Strategic Management Accounting. OMEGA, 21(6), 605-618.

Fahmi, I. (2014). Management: Theory, Cases, and Solutions. Bandung, Indonesia: Alfabeta.

Fowzia, R. (2011). Strategic Management Accounting Techniques: Relationship with Business Strategy and Strategic Effectiveness of Manufacturing Organizations in Bangladesh. World Journal of Management, 3(2), 54-69.

Furrer, O., Thomas, H., \& Goussevskaia, A. (2008). The structure and evolution of the strategic management field: A content analysis of 26 years of strategic management research. International Journal of Management Reviews, 10(1), 1-23.

Galbraith, J. (1973). Designing Complex Organization. Reading, MA: Addison-Wesley. 
Gudono. (2014). Organizational Theory (3 ${ }^{\text {rd }}$ ed.). Yogyakarta, Indonesia: BPFE.

Guilding, C., Cravens, K. S., \& Tayles, M. (2000). An International Comparison of Strategic Management Accounting Practices. Management Accounting Research, 11(1), 113-135.

Guilding, C., \& McManus, L. (2002). The incidence, perceived merit and antecedentsn of customer accounting an exploratory note. Accounting, Organizations and Society, 27(1-2), 45-59.

Hair, J. F., Hult, G. T. M., Ringle, C. M., \& Sarstedt, M. (2014). A Primer On Partial Least Squares Structural Equation Modeling (PLS-SEM). London, UK: Sage Publications.

Haldma, T., \& Lääts, K. (2002). Contingencies Influencing the Management Accounting Practices of Estonian Manufacturing Companies. Management Accounting Research 13(4), 379-400.

Hassan, N. H. N., Muhammad, N. M. N., \& Ismail, Z. (2011). Strategic Management Accounting Practice In Malaysia: Case of Manufacturing Sector. Journal of Finance, Accounting and Management, 2(2), 23-38.

Homburg, C., Krohmer, H., \& Workman, J. P. (1999). Strategic Consensus and Performance: The Role of Strategy Type and Market-Related Dynamism. Strategic Management Journal, 20(4), 339-357.

Hoque, Z. (2004). A contingency model of the association between strategy, environmental uncertainty and performance measurement: Impact on organizational performance. International Business Review, 13(4), 485-502.

Hutaibat, K., Alberti-Alhtaybat, L. V., \& Al-Htaybat, K. (2011). Strategic management accounting and the strategising mindset in an English higher education institutional context. Journal of Accounting \& Organizational Change, 7(4), 358-390.

Hutaibat, K. A. (2011). Value Chain for Strategic Management Accounting in Higher Education. International Journal of Business and Management, 6(11), 206-218.

Hyvonen, J. (2008). Linking management accounting and control systems, strategy, information technology, manufacturing technology and organizational performance of the firm in contingency framework. University of Oulu, Oulu University Press.

Kohli, A. K., \& Jaworski, B. J. (1990). Market Orientation: The Construct, Research Propositions and Management Implication. Journal of Marketing, 54(2), 1-18.

Kotler, P. (2000). Marketing Management Analysis, Planning, Implementation, and Control ( $9^{\text {th }}$ ed.). Englewood Cliff, NJ: Prentice-Hall, Inc.

Kreitner, R., \& Kinicki, A. (2001). Organizational Behavior $\left(5^{\text {th }}\right.$ ed.). New York, NY: McGraw-Hill.

Langfield-Smith, K. (1997). Management control system and strategy: A critical review. Accounting, Organizations and Society, 22(2), 207-232.

Latan, H., \& Ghozali, I. (2012). Concepts, Methods and Applications - Using the WarpPLS 2.0 Program. Semarang, Indonesia: Badan Penerbit Universitas Diponegoro.
Le, Q. B., Nguyen, M. D., Bui, V. C., \& Dang, T. M. H. (2020). The Determinants of Management Information Systems Effectiveness in Small- and Medium-Sized Enterprises. Journal of Asian Finance, Economics and Business, 7(8), 567576. doi:10.13106/jafeb.2020.vol7.no8.567

Maassen, P. A. M., \& Potmaw, H. P. (1990). Strategic decision making in higher education: An analysis of the new planning system in Dutch higher education. Higher Education 20, 393410 .

Mardiasmo. (2002). Public sector accounting. Yogyakarta, Indonesia: ANDI.

Marin, J.-C. (2012). The Impact Of Strategic Planning and The Balanced Scorecard Methodology on Middle Managers' Performance in the Public Sector. International Journal of Business and Social Science, 3(1), 114-127.

McManus, L. (2013). Customer accounting and marketing performance measures in the hotel industry: Evidence from Australia. International Journal of Hospitality Management, 33(A1-A2), 140-152.

Mia, L., \& Clarke, B. (1999). Market Competition, Management Accounting Systems and Business Unit Performance. Management Accounting Research, 10(2), 137-158.

Mohamed, R., \& Jamil, C. Z. M. (2013). Business Strategy and Performance Measurement System: A Study Of Small Medium Hotel Enterprises. In: Proceedings of the 6th International Conference of the Asian Academy of Applied Business (AAAB).

Moldovan, L. (2012). Integration of Strategic Management and Quality Assurance in the Romanian Higher Education. Procedia - Social and Behavioral Sciences, 58(October), 1458-1465.

Narver, J. C., \& Slater, S. F. (1990). The Effect of Market Orientation on Business Profitability. Journal of Marketing, 54(4), 20-35.

Nawawi, H. (2005). Strategic Management: Governmental nonprofit organization with illustrations in education ( $3^{\text {rd }}$ ed.). Yogyakarta, Indonesia: Gadjah Mada University Press.

Nguyen, H. Q., \& Le, O. T. T. (2020). Factors Affecting the Intention to Apply Management Accounting in Enterprises in Vietnam. Journal of Asian Finance, Economics and Business, 7(6), 95-107. doi: 10.13106/jafeb.2020.vol7.no6.095

Nimtrakoon, S. (2009). Organization Strategy, Management Techniques and Management Accounting Practices: Contingency Research in Thailand. The University of Hull.

Nixon, B., \& Burns, J. (2012). The paradox of strategic management accounting. Management Accounting Research, 23(4), 229-244.

Noordin, R., Zainuddin, Y., \& Tayles, M. (2009). Strategic Management Accounting Information Elements: Malaysian Evidence. Asia-Pacific Management Accounting Journal 4(1), 17-34.

Otley, D. T. (1980). The Contingency Theory of Management Accounting: Achievement and Prognosis. Accounting, Organizations and Society, 5(4), 413-428. 
Phornlaphatrachakorn, K., \& Na-Kalasindhu, K. (2020). Strategic Management Accounting and Firm Performance: Evidence from Finance Businesses in Thailand. Journal of Asian Finance, Economics and Business, 7(8), 309-321. doi: 10.13106/ jafeb.2020.vol7.no8.309

Phornlaphatrachakorn, K., \& Peemanee, J. (2020). Integrated Performance Measurement as a Strategic Management Accounting Approach: A Case of Beverage Businesses in Thailand. Journal of Asian Finance, Economics and Business, 7(8), 247-257. doi: 10.13106/jafeb.2020.vol7.no8.247

Robbins, S. P. (1994). Essential of Organizational Behavior, Fourth Edition. Englewood Cliffs, NJ: Prentice-Hall.

Roslender, R., \& Hart, S. J. (2002). Integrating Management Accounting and Marketing in The Pursuit of Competitive Advantage: The Case For Strategic Management Accounting. Critical Perspectives on Accounting, 13(2), 255-277.

Roslender, R., \& Hart, S. J. (2003). In Search Of Strategic Management Accounting: Theoretical and Field Study Perspectives. Management Accounting Research, 14(3), 255279.

Roslender, R., \& Hart, S. J. (2006). Interfunctional Cooperation in progressing accounting for brands: The case for brand management accounting. Journal of Accounting \& Organizational Change, 2(3), 229-247.

Ruekert, R. W., Walker, O. C., \& Roering, K. J. (1985). The organization of marketing activities: A contingency theory of structure and performance. Journal of Marketing, 49(1), 13-25.

Said, J., W. S. Hui, R. Othman, \& Taylor, D. (2010). The Mediating Effects Of Organizational Learning Orientation On The Relationship Between Strategic Management Accounting Information Use and Organizational Performance. Asia-Pacific Management Accounting Journal, 5(2), 11-29.

Sholihin, M., \& Ratmono, D. (2013). SEM-PLS analysis with WarpPLS 3.0 - for Nonlinear Relationships in Social and Business Research. Yogyakarta, Indonesia: Andi Offset.

Simon, C. (2007). A Configuration Form of Fit in Management Accounting Contingency Theory: An Empirical Investigation. The Business Review, 7(2), 220.

Simon, C., \& Guilding, C. (2008a). An exploratory investigation of an integrated contingency model of strategic management accounting. Accounting, Organizations and Society, 33(7-8), 836-863.

Simon, C., \& Guilding, C. (2008b). Strategy and Strategic Management Accounting: A Investigation Of Organizational Configurations. Paper presented at the Manchester Business School Research Seminar, June 18, 2008.

Simons, R. (1987). Accounting control systems and business strategy: an empirical analysis. Accounting, Organizations and Society, 12(4), 357-374.
Slater, S. F., \& Narver, J. C. (1995). Market Orientation and the Learning Organization. Journal of Marketing, 59(3), 63-74.

Smith, M. (2005). Performance Measurement \& Management: A Strategic Approach To Management Accounting: SAGE Publications Ltd.

Spicer, B. H. (1990). New directives in management accounting practice and research. Management Accounting Research, 1(2), 139 - 146.

Sriyono, \& Rahmawati. (2014). The Role of Contingency Factors in the Implementation of Strategic Management Accounting (SMA) in Private Universities/Colleges (PTSes) under Kopertis Region V of Yogyakarta. International Journal of Computer Networks and Communications Security, 2(11), 374-378.

Sugiyono. (2010). Quantitative Research Methods, Qualitative, and $R \& D$. Bandung, Indonesia: Afabeta.

Tayles, M., Bramley, A., Adshead, N., \& Farr, J. (2002). Dealing with the management of intellectual capital: The potential role of strategic management accounting. Accounting, Auditing \& Accountability Journal, 15(2), 251-267.

Tayles, M., Pike, R. H., \& Sofian, S. (2007). Intellectual capital, management accounting practices and corporate performance: Perceptions of managers. Accounting, Auditing \& Accountability Journal, 20(4), 522-548.

Torang, S. (2013). Organization \& Management (Behavior, Structure, Culture \& Organizational Change). Bandung, Indonesia: Alvabeta.

Uha, I. N. (2013). Organizational Culture Leadership and Performance: Formed Processes, Growth and Development, Organizational Dynamics and Performance. Jakarta, Indonesia: Kencana Prenadamedia Group.

Varadarajan, P. R., \& Jayachandran, S. (1999). Marketing Strategy: An Assessment of the State of the Field and Outlook. Journal of the Academy of Marketing Science, 27(2), 120-143.

Wheelen, T. L., \& Hunger, J. D. (1996). Strategic Management ( $5^{\text {th }}$ ed.). Reading, MA: Addison-Wesley Publishing.

Wheelen, T. L., \& Hunger, J. D. (2012). Strategic Management and Business Policy: Toward Global Sustainability (13 ${ }^{\text {th }}$ ed.). Upper Saddle River, NJ: Prentice Hall.

Wursanto, I. (2003). Fundamentals of Organizational Science. Yogyakarta, Indonesia: ANDI.

Yani, A. (2014). Analysis of the Relationship of Using Competitive Strategies and Organizational Performance in Higher Education. Jurnal Ilmu Manajemen, Revitalisasi, 3(4), 33-50.

Zenita, R., Sari, R. N., Anugerah, R., \& Said, J. (2015). The Effect of Information Literacy on Managerial Performance: The Mediating Role of Strategic Management Accounting and the Moderating Role of Self Efficacy. Procedia Economics and Finance, 31(2015), 199-205. 